\title{
Description of 22 new alpha-1 antitrypsin genetic variants
}

\author{
Céline Renoux ${ }^{1,2+}$, Marie-Françoise Odou ${ }^{3,4^{*}+} \mathbb{D}$, Guillaume Tosato ${ }^{3}$, Jordan Teoli ${ }^{1}$, Norman Abbou ${ }^{1}$, \\ Christine Lombard ${ }^{5}$, Farid Zerimech ${ }^{3,6}$, Nicole Porchet ${ }^{3}$, Colette Chapuis Cellier ${ }^{5+}$, Malika Balduyck ${ }^{3,7+}$ \\ and Philippe Joly ${ }^{1,2+}$
}

\begin{abstract}
Alpha-1 antitrypsin deficiency is an autosomal co-dominant disorder caused by mutations of the highly polymorphic SERPINA1 gene. This genetic disorder still remains largely under-recognized and can be associated with lung and/or liver injury. The laboratory testing for this deficiency typically comprises serum alpha-1 antitrypsin quantification, phenotyping according to the isoelectric focusing pattern and genotyping if necessary. To date, more than 100 SERPINA1 variants have been described and new genetic variants are frequently discovered. Over the past 10 years, 22 new genetic variants of the SERPINA1 gene were identified in the daily practice of the University Medical laboratories of Lille and Lyon (France). Among these 22 variants, seven were Null alleles and one with a $\mathrm{M} 1$ migration pattern ( $\mathrm{M} 1_{\text {Cremeaux }}$ ) was considered as deficient according to the clinical and biological data and to the American College of Medical Genetics and Genomics (ACMG) criteria. Three other variants were classified as likely pathogenic, three as variants of uncertain significance while the remaining ones were assumed to be neutral. Moreover, we also identified in this study two recently described SERPINA1 deficient variants: Trento (p.Glu99Val) and SDonosti (p.Ser38Phe). The current data, together with a recent published meta-analysis, represent the most up-to-date list of SERPINA1 variants available so far.
\end{abstract}

Keywords: Alpha-1 antitrypsin deficiency, SERPINA1 genotyping, Null alleles

Alpha-1 antitrypsin (A1AT) is the main circulating protease inhibitor, protecting the lung parenchyma against proteolytic attacks. Alpha-1 antitrypsin deficiency (AATD) is a common but still largely under-recognized genetic disorder. It predisposes to liver and lung diseases and rarely to granulomatosis with polyangiitis and necrotizing panniculitis [1]. The wild-type allele is called $P I^{*} M$ while the most common deficient alleles are known as $P I^{*} S$ and $P I * Z$, according to their isoelectrofocusing (IEF) pattern. AATD-associated liver disease, observed for the deficient variants $\mathrm{Z}, \mathrm{S}_{\text {Iiyama }}$ and $\mathrm{M}_{\text {Malton }}$, can be attributed to intracellular polymerization of the misfolded protein leading to

\footnotetext{
* Correspondence: marie-francoise.odou@chru-lille.fr

${ }^{\dagger}$ Céline Renoux, Marie-Françoise Odou, Colette Chapuis Cellier, Malika

Balduyck and Philippe Joly contributed equally to this work.

${ }^{3}$ Service de Biochimie et Biologie moléculaire "Hormonologie,

Métabolisme-Nutrition, Oncologie", CHU Lille, F-59000 Lille, France

${ }^{4}$ Faculty of Pharmaceutical and Biological Sciences, UMR995, LIRIC (Lille

Inflammation Research International Center), University of Lille, F-59000 Lille,

France

Full list of author information is available at the end of the article
}

endoplasmic reticulum storage disease. Mild liver storage is observed with the $S$ variant which is probably degraded before secretion [2].

The medical indications for AATD screening were either a pulmonary or hepatic disorder or when a routine protein electrophoresis fortuitously revealed a splitting (with or without decrease) of the $\alpha_{1}$-globulin fraction at protein electrophoresis. The biochemistry laboratories of the academic medical centers of Lyon and Lille (France) currently investigate AATD by serum immunochemical quantification and IEF of A1AT. In the laboratory of Lyon, IEF is carried out on polyacrylamide gels based on the method previously described [3] with slight modifications of $\mathrm{pH}$ gradient (4.2-4.9). In the laboratory of Lille, IEF is performed on agarose gels using commercially available kits and immuno-enzymatic revelation (Sebia, Evry, France) [4]. In both laboratories, A1AT inhibitory activity may also be assessed through the serum elastase inhibitory capacity (SEIC) which relies on the inhibition measurement of the hydrolytic 
activity of the porcine pancreatic elastase by A1AT on a chromogenic substrate (N-Succinyl-Ala-Ala-Ala-p-nitroanilide). This kinetic spectrophotometric test, adapted from the method previously described by Klumpp and Bieth [5], was developed in close collaboration by the two laboratories so that the results could be comparable [6]. Using the correlation between A1AT concentration and SEIC, a theoretical SEIC can be calculated and compared to the measured SEIC with $\mathrm{R}$ being the ratio between the measured SEIC and the expected SEIC. For patients in heterozygosity with a new variant, $\mathrm{R}$ below 0.8 is presumptive of a dysfunctional variant.

This combination of techniques is sufficient to characterize up to $95 \%$ of A1AT abnormalities, mainly ZZ, SZ and SS phenotypes [1, 6, 7]. For the other cases (i.e. unexplained low A1AT level, unusual IEF pattern or IEF pattern inconsistent with clinical history), Sanger sequencing of the SERPINA1 gene including coding exons, $5^{\prime}$ and $3^{\prime}$ untranslated regions (UTRs) and splice boundaries is performed and can be extended to intronic sequences by Next Generation Sequencing technology [8]. All sequence variations are named according to the Human Genome Variation Society (HGVS) and using the reference transcript NM_000295.4 which includes the 24 residues of the signal peptide.

Over the past 10 years, more than 1200 A1AT genotyping analyses performed in our two centers led to the identification of 22 new variants in 35 patients aged from 7 to 81 years (Table 1 and Fig. 1). It is noteworthy that 4 of them were already cited but neither named nor phenotypically or clinically described [9]. According to their IEF pattern and the birth place of the probands, we named them $S_{\text {Roubaix }}, W_{\text {Saint-Avre, }} M 1_{\text {Lille }}$ and $M 1_{\text {Lyon }}$. The criteria of the American College of Medical Genetics and Genomics (ACMG) were used to classify these 22 variants as benign, likely benign, of uncertain significance, likely pathogenic, or pathogenic [10]. Since we did not have the possibility to test them in expression vectors like HEK293T/17 or Hepa1-6 cells, the available clinical and biochemical data of A1AT were considered, as well as the results of two in silico pathogenicity predictors, shown to have a sensitivity of 0.75 for SERPINA1 mutations [11]. The first one, namely SIFT for Sorting Intolerant From Tolerant, ranges from 0.00 to 1 and is mainly based on amino-acid conservation scores. A SIFT score between 0 and 0.05 is highly predicting of an affected protein function. The second one, namely PolyPhen-2 HVAR, proposes a prediction confidence score between 0.00 and 1.00 which uses multiple alignment and protein structural data. A PolyPhen-2 score higher than 0.8 is considered as probably damaging. The recently described REVEL (for Rare Exome Variant Ensemble Learner) method [12] was also used since it had been shown to be the most suitable one for the prediction of pathogenic A1AT variants [11]. Briefly, a REVEL score of less than 0.354 is highly predictive of a benign character of the variant whereas a score of more than 0.618 is highly predictive of pathogenicity.

Seven new variants were assumed to be Null ones: Q0 $0_{\text {Lille }}, \mathrm{Q0} 0_{\text {Casablanca, }}, \mathrm{Q} 0_{\text {Saint-Etienne, }} \mathrm{Q} 0_{\text {Achicourt }}, \mathrm{Q} 0_{\text {Saint-A- }}$ vold, $\mathrm{Q} 0_{\text {Amiens }}$ and $\mathrm{Q} 0_{\text {Montluel. }}$. They resulted from splice-site, non-sense or frame shift mutations leading to premature stop codons with biosynthesis of truncated proteins or pre-mRNA degradation by the nonsense mediated decay mechanism. Interestingly, the c.288_291del frame shift mutation gives rise to two different $S E R$ PINA1 Null variants which are associated with distinct genetic backgrounds: $\mathrm{M} 2$ for $\mathrm{Q}_{\text {Casablanca }}$ and $\mathrm{Z}$ for $\mathrm{Q} \mathrm{O}_{\mathrm{Lill}}$. The c.559A > T (Q0 Saint-Etienne $)$ and c.1237_1239del ( $\mathrm{Q} 0$ Montluel $)$ mutations lead to a premature stop codon while $\mathrm{Q} 0_{\text {Achicourt }}, \mathrm{Q} 0_{\text {Saint-Avold }}$ and $\mathrm{Q} 0_{\text {Amiens }}$ are caused by splicing abnormalities. It is noteworthy that $\mathrm{Q} 0_{\text {Achicourt }}$ and $\mathrm{Q} 0_{\text {Saint-Avold, }}$ found in young patients presenting with emphysema, were both in compound heterozygosity with another deficient SERPINA1 allele $\left(\mathrm{Q}_{\text {Clayton }}\right.$ and $\mathrm{Z}$, respectively).

The $\mathrm{M} 1_{\text {Cremeaux }}$ variant was identified in four members of a same family (two sisters and their sons). The propositus was a 36-year-old woman without any pulmonary or hepatic disorder harboring the $\mathrm{M} 1_{\text {Cremeaux }}$ variant in heterozygosity with the dysfunctional $\mathrm{Z}$ variant. A1AT biochemical analysis was prescribed because of low $\alpha_{1}$-globulin fraction at protein electrophoresis during a hair loss exploration. Despite the absence of any specific clinical impact, $M 1_{\text {Cremeaux }}$ was considered as a deficient A1AT variant (ACMG class5) for four reasons: (i) the A1AT serum level was significantly decreased $(0.23 \mathrm{~g} / \mathrm{L}$ in heterozygosity with the $\mathrm{Z}$ allele and from 0.88 to $1.01 \mathrm{~g} / \mathrm{L}$ in association with a M1 or M2 allele), (ii) the mutation was located at the beginning of the $5 \mathrm{~A} \beta$-strand which is an important region for the protein stability [1] (iii) the pathogenic A1AT King variant affects the same amino-acid (p.His358Asp) [13] and (iv) the SIFT score (0.48) was normal but the PolyPhen-2 and REVEL scores (0.999 and 0.650) were highly predictive of pathogenicity.

The two $\mathrm{P}$ variants, $\mathrm{P}_{\text {Loyettes }}$ and $\mathrm{P}_{\text {Solaize, }}$ were suspected to be dysfunctional according to their decreased elastase inhibitory activity demonstrated by $\mathrm{R}$ values of 0.62 and 0.79 , respectively. Sustaining our hypothesis, REVEL, SIFT and PolyPhen-2 scores predicted $\mathrm{P}_{\text {Loyettes }}$ (0.933, 0 and 1.00, respectively) and $P_{\text {Solaize }}(0.597,0$ and 0.623 , respectively) as deleterious. The $\mathrm{W}_{\text {vernaison }}$ variant also harbored a decreased elastase inhibitory activity ( $R$ value 0.79 ) and an IEF pattern with almost undetectable bands; nevertheless, SIFT and PolyPhen-2 scores predicted it as benign ( 0.08 and 0.432 respectively) but not the REVEL score of 0.638 . Moreover, these three variants were identified in patients with an inflammatory 


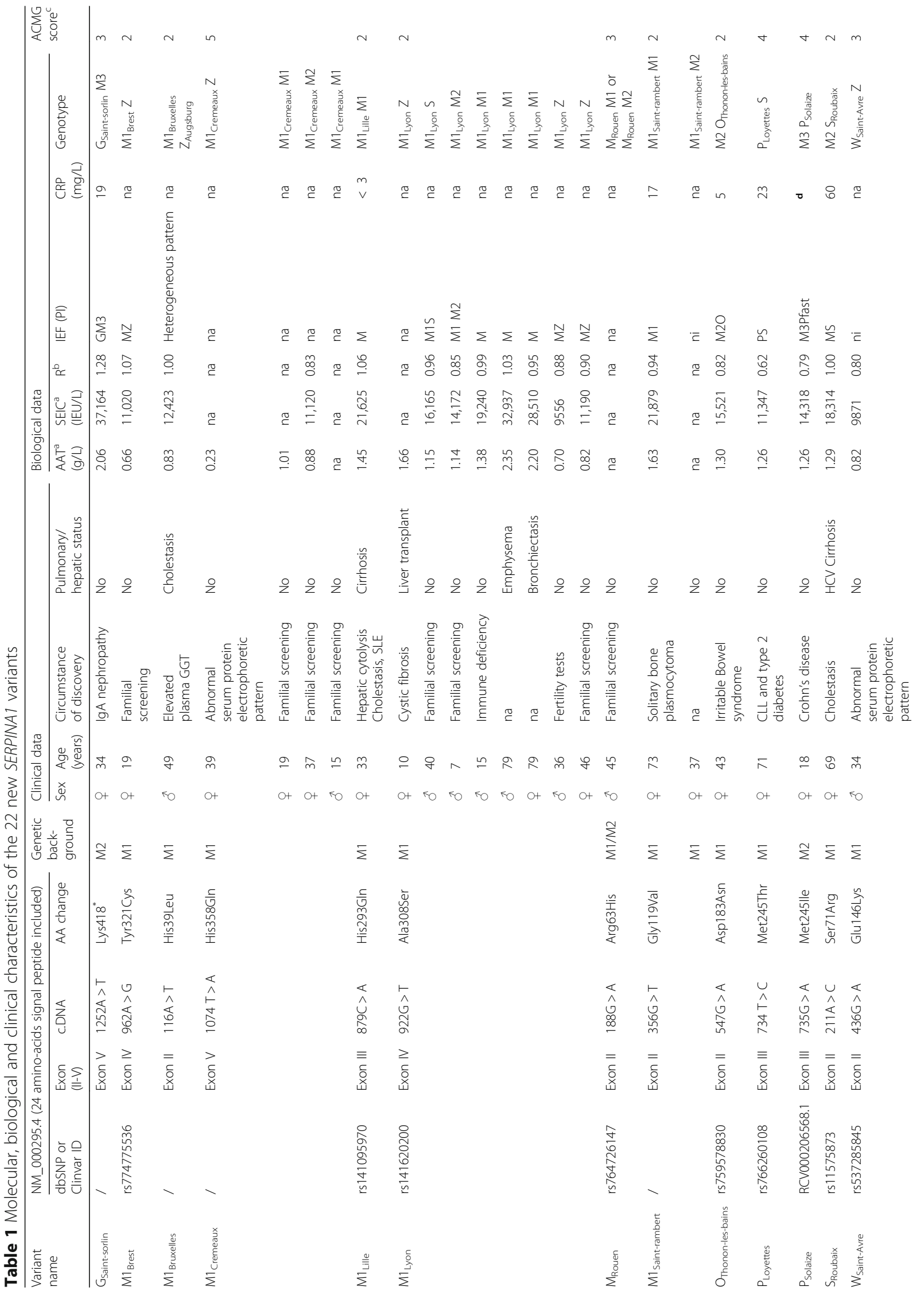


Renoux et al. Orphanet Journal of Rare Diseases (2018) 13:161

Page 4 of 7

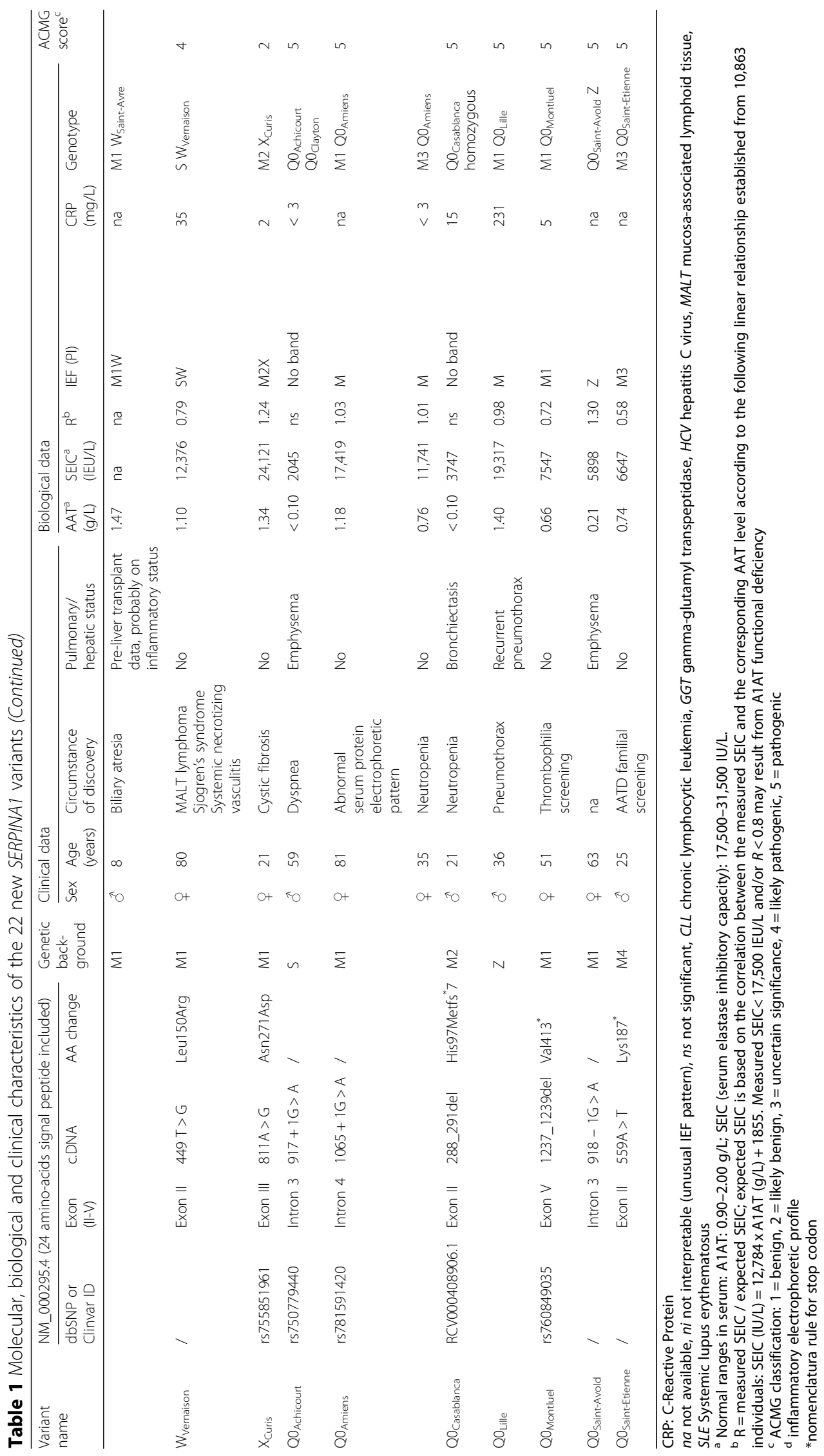




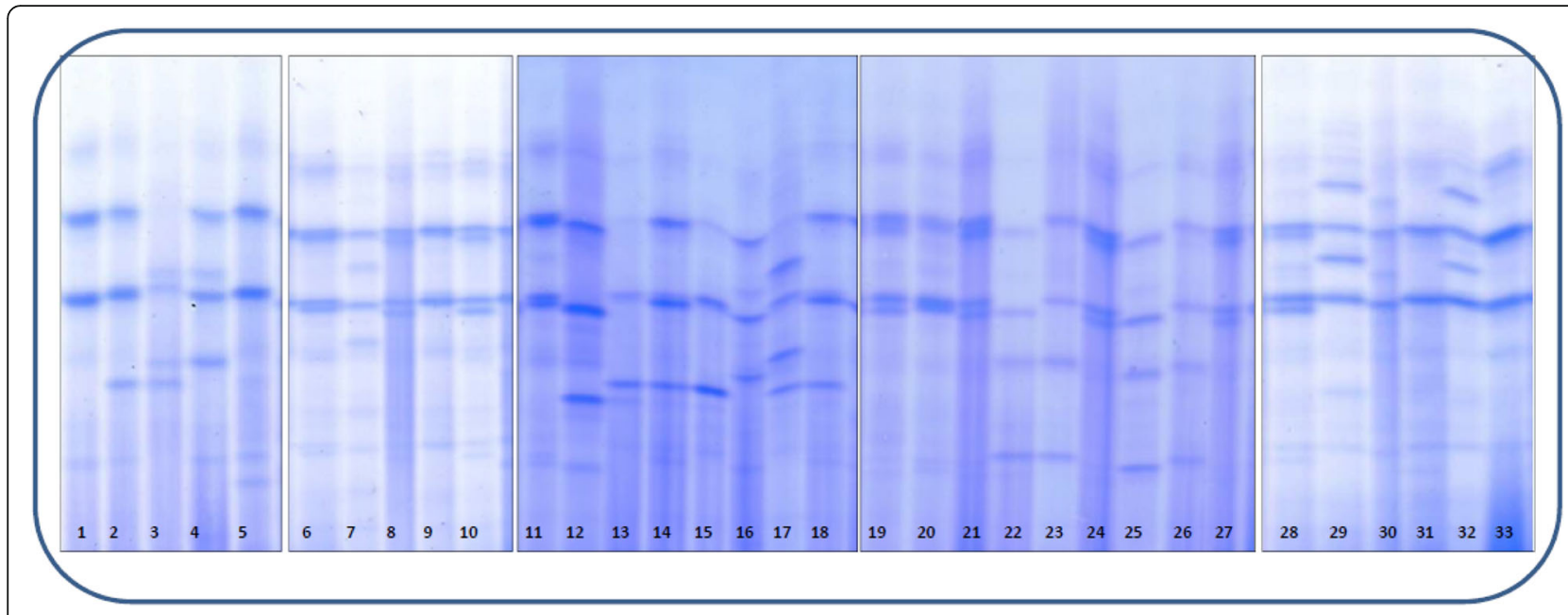

Fig. $1 \mathrm{IEF}$ patterns of some frequent and rare A1AT phenotypes (polyacrylamide gels with Coomassie blue staining). 1, 33: $M_{1} M_{3} ; 2,15,18: M_{1} S_{i} 3,17$ :

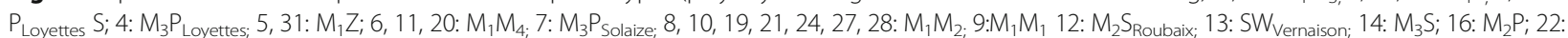

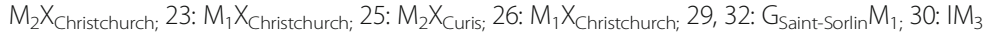

status (CRP plasma levels higher than $10 \mathrm{mg} / \mathrm{L}$ ) that probably led to overestimation of the recorded A1AT levels. They were thus classified as likely pathogenic according to ACMG criteria (class 4).

While caused by a non-sense mutation, A1AT $\mathrm{G}_{\text {Saint-- }}$ Sorlin (c.1252A > T; p.Lys418*) was ranged as variant of uncertain significance (class 3) since the A1AT biochemical data were normal. As the premature stop codon is located on the very last triplet of the gene, the final protein lacks only one amino-acid and it seems to have no consequence on its synthesis or functional activity. Conversely, the $\mathrm{M} 1_{\text {Rouen }}$ variant was also ranged in class 3 and not considered as benign or likely benign because: (i) it appears at very low allelic frequencies in databases (ExAC and Topmed: 0.0012\%), (ii) a pathogenic variant on the same amino-acid (namely, the I variant p.Arg63Cys) has been described and (iii) we could not get any serum sample to assess A1AT quantification and SEIC. In detail, the SIFT and PolyPhen-2 algorithms classify the I variant as deleterious ( 0 and 1 , respectively) while they are contradictory for the $\mathrm{M} 1_{\text {Rouen }}$ variant ( 0.04 and 0.185 , respectively). A border-line $R$ ratio of 0.8 was obtained for an asymptomatic 34 -year

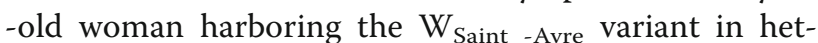
erozygosity with the dysfunctional $\mathrm{Z}$ variant. According to its low frequency in databases (ExAC: $0.0032 \%$ ) and to its SIFT and PolyPhen-2 scores (1 and 0.000 respect-

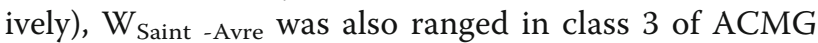
classification.

The remaining eight variants were classified as likely benign (class 2) because in silico algorithms predicted no impact on gene product and the A1AT quantitation and SEIC measures revealed no abnormality.
Very interestingly, we also identified during the course of this study two SERPINA1 deficient variants that were very recently described: Trento (p.Glu99Val) [14] and $S_{\text {Donosti }}$ (p.Ser38Phe) [15]. The Trento variant showed compromised conformational stability after secretion from the hepatocyte [14]. In our cohort, this variant was present in heterozygosity with the $\mathrm{M}_{\text {Malton }}$ variant in a 42-year-old man with a low A1AT level $(0.85 \mathrm{~g} / \mathrm{L})$ presenting with hepatic fibrosis. The $\mathrm{S}_{\text {Donosti }}$ variant was shown to form intra-cellular polymers that prevent its secretion from the hepatocytes. We identified the $\mathrm{S}_{\text {Donosti }}$ variant in two unrelated individuals (in heterozygosity with the M1 variant and with the $\mathrm{S}$ variant, respectively): (i) a 64-year-old woman suffering from emphysema (A1AT level = $1.21 \mathrm{~g} / \mathrm{L}$ but inflammatory status not known) and (ii) a 41-year-old man suffering from hemochromatosis $($ A1AT level $=0.80 \mathrm{~g} / \mathrm{L}$ ).

In conclusion, this study highlights the importance of the whole SERPINA1 gene sequencing (and not only the specific research of the $\mathrm{Z}$ and $\mathrm{S}$ variants) to explain some AATD clinical and biological pictures. Among these 22 new A1AT variants, a significant percentage of severely deficient ones (class 5) was observed (36.4\%): Seven Q0 alleles and one deficient $\mathrm{M} 1$ allele $\left(\mathrm{M} 1_{\text {Cremeaux }}\right)$. Three variants $\left(\mathrm{P}_{\text {Loyettes }}, \mathrm{P}_{\text {Solaize }}\right.$ and $\left.\mathrm{W}_{\text {Vernaison }}\right)$ could be classified as dysfunctional variants (class 4) mainly because of their reduced elastase inhibitory activity. Three variants $\left(\mathrm{M} 1_{\text {Rouen }}, \mathrm{G}_{\text {Saint -Sorlin }}\right.$ and $\left.\mathrm{W}_{\text {Saint -Avre }}\right)$ were classified as variants of uncertain significance (Class 3 ) and the eight remaining ones as likely benign (Class 2 ). To note, we fortuitously observed that the IEF pattern of the $S_{\text {Roubaix }}$ variant depended on the migration medium: W-like on polyacrylamide gels (Lyon) and S-like on agarose gels 
(Lille) (Additional file 1: Figure S1). Since all patients carrying the $S_{\text {Roubaix }}$ variant were of North African origin, we highly speculate that this variant might correspond to the 'old' W3 $3_{\text {Constantine described in }}$ 1977 by Khitri [16]. The recent meta-analysis by Silva et al., completed by the present data, represents the most up-to-date list of SERPINA1 variants available so far.

\section{Additional file}

Additional file 1: Figure S1. A1AT phenotypes: (A) Coomassie blue stained polyacrylamide gel (B) agarose gel followed by immunofixation. 1: $M_{1} ; 2: M_{2} S ; 3: M_{1} M_{4} ; 4,5,6: M_{2} P ; 7: M_{2} S_{\text {Roubaix; }}$ : IM; 9: $M_{2} S_{\text {Roubaixi }}$ 10,11:M $Z$; 12: $\mathrm{M}_{1} ; 13: \mathrm{M}_{2} \mathrm{~S} ; 14: \mathrm{M}_{1} \mathrm{~S}$. The $\mathrm{S}_{\text {Roubaix }}$ variant has clearly different patterns of migration on polyacrylamide and on agarose gels. (PPTX $217 \mathrm{~kb}$ )

\section{Abbreviations}

A1AT: Alpha-1-antitrypsin; AATD: Alpha-1-antitrypsin deficiency; IEF: Isoelectric focusing; SEIC: Serum elastase inhibitory capacity

\section{Acknowledgements}

We thank the technical teams of the laboratories of Lyon and Lille for their skillful assistance. We are also very grateful to all the patients and their medical doctors.

\section{Funding}

This work was funded by the 'Hospices Civils de Lyon ( $\mathrm{HCL})^{\prime}$ and by the 'Centre Hospitalier Régional Universitaire (CHRU) de Lille'.

\section{Availability of data and materials}

The dataset supporting the conclusions of this article is included within the article and its additional files.

\section{Authors' contributions}

Biochemical and genetic analysis: CR, MFO, NP, FZ, CCC, MB, PJ. Made substantial contribution to acquisition of data, analysis and interpretation of data: CR, MFO, CL, GT, JT, NA, NP, FZ, CCC, MB, PJ. Drafting manuscript: CR, $M F O, F Z, C C C, M B, P J$. Revising and approving content: CR, MFO, FZ, CCC, MB, PJ. Given final approval: CR, MFO, CL, GT, JT, NA, NP, FZ, CCC, MB, PJ.

\section{Ethics approval and consent to participate}

Written informed consents were obtained from all patients for the genetic analyses.

\section{Consent for publication}

Consents for research use of the data are included in the informed consent signed by the patients.

\section{Competing interests}

The authors declare that they have no competing interests.

\section{Publisher's Note}

Springer Nature remains neutral with regard to jurisdictional claims in published maps and institutional affiliations.

\section{Author details}

'Laboratoire de Biochimie et Biologie moléculaire Grand Est, UF "Biochimie des pathologies érythrocytaires", Centre de Biologie et de Pathologie Est, Hospices Civils de Lyon, Lyon, France. ${ }^{2}$ Laboratoire Interuniversitaire de Biologie de la Motricité (LIBM) EA7424, Team "Vascular Biology and Red Blood Cell", Université Claude Bernard Lyon 1, Villeurbanne, France. ${ }^{3}$ Service de Biochimie et Biologie moléculaire "Hormonologie, Métabolisme-Nutrition, Oncologie", CHU Lille, F-59000 Lille, France. "Faculty of Pharmaceutical and Biological Sciences, UMR995, LIRIC (Lille Inflammation Research International Center), University of Lille, F-59000 Lille, France. ${ }^{5}$ Laboratoire d'Immunologie,
Centre Hospitalier Lyon-Sud, Hospices Civils de Lyon \& Université Claude Bernard-Lyon 1, Lyon, France. ${ }^{6} E A 4483$, IMPECS, Institut Pasteur de Lille, University of Lille, F-59000 Lille, France. ${ }^{7}$ Faculty of Pharmaceutical and Biological Sciences, EA7364, RADEME (Research team on rare developmental and metabolic diseases), University of Lille, F-59000 Lille, France.

Received: 26 April 2018 Accepted: 23 August 2018

Published online: 17 September 2018

\section{References}

1. Greene CM, Marciniak SJ, Teckman J, Ferrarotti I, Brantly ML, Lomas DA, Stoller JK, NG ME. Alpha1-antitrypsin deficiency. Nat Rev Dis Primers. 2016;2: 16051. https://doi.org/10.1038/nrdp.2016.51.

2. Callea F, Giovannoni I, Francalanci P, Boldrini R, Faa G, Medicina D, Nobili V, Desmet VJ, Ishak K, Seyama K, Bellacchio E. Mineralization of alpha-1antitrypsin inclusion bodies in Mmalton alpha-1-antitrypsin deficiency. Orphanet J Rare Dis. 2018;13 https://doi.org/10.1186/s13023-018-0821-7.

3. Arnaud P, Chapuis-Cellier C. Alpha 1-antitrypsin. Methods Enzymol. 1988; 163:400-18.

4. Zerimech F, Hennache G, Bellon F, Barouh G, Jacques Lafitte J, Porchet N, Balduyck M. Evaluation of a new Sebia isoelectrofocusing kit for alpha 1 antitrypsin phenotyping with the Hydrasys system. Clin Chem Lab Med. 2008;46(2):260-3. https://doi.org/10.1515/CCLM.2008.036

5. Klumpp T, Bieth JG. Automated measurement of the elastase-inhibitory capacity of plasma with a centrifugal analyzer. Clin Chem. 1979;25(6): 969-72.

6. Balduyck M, Odou MF, Zerimech F, Porchet N, Lafitte JJ, Maitre B. Diagnosis of alpha-1 antitrypsin deficiency: modalities, indications and diagnosis strategy. Rev Mal Respir. 2014;31(8):729-45. https://doi.org/10.1016/j.rmr. 2014.06.001.

7. Stockley RA, Luisetti M, Miravitlles M, Piitulainen E, Fernandez P. Alpha one international registry group: ongoing research in Europe: alpha one international registry (AIR) objectives and development. Eur Respir J. 2007; 29(3):582-6. https://doi.org/10.1183/09031936.00053606.

8. Joly P, Francina A, Lacan P, Heraut J, Chapuis-Cellier C. Place of genotyping in addition to the phenotype and the assay of serum alpha-1 antitrypsin. Ann Biol Clin. 2011:69(5):571-6. https://doi.org/10.1684/abc.2011.0613.

9. Silva D, Oliveira MJ, Guimaraes M, Lima R, Gomes S, Seixas S. Alpha-1antitrypsin (SERPINA1) mutation spectrum: three novel variants and haplotype characterization of rare deficiency alleles identified in Portugal. Respir Med. 2016;116:8-18. https://doi.org/10.1016/j.rmed.2016.05.002.

10. Richards S, Aziz N, Bale S, Bick D, Das S, Gastier-Foster J, Grody WW, Hegde M, Lyon E, Spector E, Voelkerding K, Rehm HL, Committee ALQA. Standards and guidelines for the interpretation of sequence variants: a joint consensus recommendation of the American College of Medical Genetics and Genomics and the Association for Molecular Pathology. Genet Med. 2015; 17(5):405-24. https://doi.org/10.1038/gim.2015.30.

11. Giacopuzzi E, Laffranchi M, Berardelli R, Ravasio V, Ferrarotti I, Gooptu B, Borsani G, Fra A. Real-world clinical applicability of pathogenicity predictors assessed on SERPINA1 mutations in alpha-1-antitrypsin deficiency. Hum Mutat. 2018; https://doi.org/10.1002/humu.23562.

12. Ioannidis NM, Rothstein JH, Pejaver V, Middha S, McDonnell SK, Baheti S, Musolf A, Li Q, Holzinger E, Karyadi D, Cannon-Albright LA, Teerlink CC, Stanford JL, Isaacs WB, Xu J, Cooney KA, Lange EM, Schleutker J, Carpten JD, Powell IJ, Cussenot O, Cancel-Tassin G, Giles GG, Maclnnis RJ, Maier C, Hsieh CL, Wiklund F, Catalona WJ, Foulkes WD, Mandal D, Eeles RA, Kote-Jarai Z, Bustamante CD, Schaid DJ, Hastie T, Ostrander EA, Bailey-Wilson JE, Radivojac P, Thibodeau SN, Whittemore AS, Sieh W. REVEL: an ensemble method for predicting the pathogenicity of rare missense variants. Am J Hum Genet. 2016;99(4):877-85. https://doi.org/10.1016/j.ajhg.2016.08.016.

13. Miranda E, Perez J, Ekeowa UI, Hadzic N, Kalsheker N, Gooptu B, Portmann B, Belorgey D, Hill M, Chambers S, Teckman J, Alexander GJ, Marciniak SJ, Lomas DA. A novel monoclonal antibody to characterize pathogenic polymers in liver disease associated with alpha1-antitrypsin deficiency. Hepatology. 2010;52(3):1078-88. https://doi.org/10.1002/hep.23760.

14. Miranda E, Ferrarotti I, Berardelli R, Laffranchi M, Cerea M, Gangemi F, Haq I, Ottaviani S, Lomas DA, Irving JA, Fra A. The pathological Trento variant of alpha-1-antitrypsin (E75V) shows nonclassical behaviour during polymerization. FEBS J. 2017;284(13):2110-26. https://doi.org/10.1111/febs.14111.

15. Matamala N, Lara B, Gomez-Mariano G, Martinez S, Retana D, Fernandez T, Silvestre RA, Belmonte I, Rodriguez-Frias F, Vilar M, Saez R, Iturbe I, Castillo S, 
Molina-Molina M, Texido A, Tirado-Conde G, Lopez-Campos JL, Posada M, Blanco I, Janciauskiene S, Martinez-Delgado B. Characterization of novel missense variants of SERPINA1 gene causing Alpha-1 antitrypsin deficiency. Am J Respir Cell Mol Biol. 2017 https://doi.org/10.1165/rcmb.2017-01790C.

16. Khitri A, Benlatrache K, Martin JP. Pi W3 Constantine, new allele of Pi system. Sem Hop. 1977;53(16):909-10.

Ready to submit your research? Choose BMC and benefit from:

- fast, convenient online submission

- thorough peer review by experienced researchers in your field

- rapid publication on acceptance

- support for research data, including large and complex data types

- gold Open Access which fosters wider collaboration and increased citations

- maximum visibility for your research: over $100 \mathrm{M}$ website views per year

At $B M C$, research is always in progress.

Learn more biomedcentral.com/submissions 